respect, owing to their peculiar power of imagining all the missing parts, just as in an ordinary telephone conversation the listener himself occasionally pro* vides as much as fifty per cent of the intelligibility. It was mentioned that there is a good deal of evidence to show that many receivers accept high-frequency energy over a far wider range of frequency than is necessary. The result is that they suffer from serious interference, as the waves of transmissions on neighbouring frequencies and the programmes they carry are also heard. It would obviously be better to limit the high-frequency range. The question of whether the average purchaser of a broadcast receiver can be entrusted to get the best results from a sharply tuned high-frequency circuit is one that can only be settled by statisties.

\section{Fisheries of the Thames Estuary}

IN a note in NATURE of May 11, 1927, attention was directed to the unpublished reports of Dr. James Murie on the Thames Estuary fisheries. Before his death in 1925, Dr. Murie had published the first part of his "Report on the Fisheries of the Thames Estuary ", containing Sections I to 3 and the greater part of Section 4. The second part, consisting of a large folio volume now in the Southend Public Library, was not published. Part of this is in galley proof, but the sixth section is in manuscript, and was written probably between 1895 and 1912. It was found in 1926 in an outhouse of Dr. Murie's cottage at Leigh, and consisted of a sodden mass of paper. The sheets were carefully separated, dried, and transscribed by the Borough Librarian, Mr. Pollitt, and a digest of this unpublished section is embodied in a long article by Mr. A. Laurence Wells, published in the Southend Standard (Jan. 7 and 14, 1931), entitled "Special Thames Estuary Fisheries". The matter is full of interest and covers a wide field. It consists mainly of detailed notes on the various fisheries in the Thames Estuary, especially those relating to the Leigh fishermen, and embraces the history of many of the older industries and the methods employed, both ancient and modern. These carefully collected data about each individual fishery are of historical value. Many of the methods are now obsolete, but most of the fisheries themselves are still flourishing.

Whitebaiting is a comparatively recent industry among the Leigh fishermen. Some two hundred year's ago it was practised up the river beyond Blackwall, but pollution of the water has driven the whitebait more to the Thames mouth, where the fishing is principally carried on. At first they fished only in spring, then in the original season from February to August; now they fish throughout the year. Shrimping, on the other hand, is an industry of long standing, begun. about a hundred years ago. Starfish dredging used to be profitable, now it is almost extinct. The fivefinger star is a great enemy of the oyster, and in dredging for them the fishermen not only helped the oyster but also utilised the starfish by selling them to the farmer for manure. Now, however, owing to chemical manure, the farmer no longer wants them. Other enemies which are much dreaded both by the whitebaiters and the shrimpers are the jelly-fishes and ctenophores, known by them as 'flat gall' and 'nut gall'. These come swarming from the sea during April and May, clogging the nets so that a continual and wearisome sorting is necessary. This manuscript is an important addition to the literature concerning the Thames Estuary fisheries, and all workers on the subject are indebted to those who have made it available to the public. Although containing about 22,000 words, it is obviously unfinished, for further sections were indicated consisting of notes on many other specialised forms of fishing.

\section{Geodesy in India}

The Geodetic Report of the Survey of India, vol. 6, deals with the very varied and extensive work done during the period Oct. 1929 Sept. 1930. A regular latitude variation programme has been started, supplementing the regular longitude observations, and in due course will throw light on the existence or otherwise of crustal drift. The irregularities in the longitude results remain unexpectedly large: to improve the time-keeping, a Shortt clock has been obtained. The form of the geoid in India and the gravity work have now brought irrefutable confirmation of Burrard's Hidden Range, which at first was inferred from rather scanty deflexion data; the Hidden Range is found to be flanked on both sides by troughs. Again, the levelling results obtained in Bengal during the last seventy years have been discussed. The closing errors of the various circuits are found to be surprisingly large, much greater than should occur in the class of levelling explained. It appears that they can be simply and naturally explained by supposing that real changes of level have occurred. Parts of the alluvial plains of northern Bengal and Bihar seem to have been rising at the rate of one foot in twenty years; tidal records indicate that Calcutta is not sinking, so that the country farther north is presumed to be rising. Further, tidal predictions for the Indian Ocean have been published in a new and cheap form of greatly increased scope, on lines similar to those of the Admiralty Tide Tables.

\section{British Museum (Natural History) Acquisitions}

Among the recent acquisitions by the Department of Zoology are two important gifts from the Rowland Ward trustees, namely, the skull and horns of a fine specimen of the giant sable antelope from Angola and a group of the little ant-eater from northern Brazil. A valuable collection of birds has been received from Mr. R. E. Moreau, secretary and librarian of the East African Agricultural Research Station at Amani, Tanganyika Territory. This collection, which was made by the aid of a grant from the Godman Exploration Fund, consists of some four hundred specimens belonging to about two hundred species, of which eight appear to be new to science. Acquisitions in the Department of Minerals include a large block of granite showing quartz-porphyry and a vein of aplite, from Penryn, Cornwall, presented by Mr. Ernest H. Davison; samples of platinum ore from Southern Rhodesia, presented by the director, Geological Survey of Southern Rhodesia, and specimens from 